\title{
札幌医大式性機能質問紙の妥当性に関する検討
}

\author{
札幌医科大学医学部泌尿器科学講座 \\ 加藤 隆一 佐藤 嘉一 堀田 浩貴 \\ 伊藤 直樹 熊本 悦明 塚本 泰司
}

札幌医科大学医学部公衆衛生学講座

三宅 浩 次

\section{VALIDITY ANALYSIS OF SAPPORO MEDICAL UNIVERSITY-SEXUAL FUNCTION QUESTIONNAIRE}

\author{
Ryuichi Kato ${ }^{1)}$, Yoshikazu Sato ${ }^{1)}$, Hiroki Horita ${ }^{1)}$, Naoki Ito ${ }^{1)}$, Yoshiaki Kumamoto ${ }^{1)}$, \\ Taiji Tsukamoto ${ }^{1)}$ and Kohji Miyake ${ }^{2)}$ \\ ${ }^{1)}$ Department of Urology, Sapporo Medical University School of Medicine \\ ${ }^{2)}$ Department of Public health, Sapporo Medical University School of Medicine
}

(Background) We evaluated the validity of the Sapporo Medical University-sexual function questionnaire, comparing the response to each question of patients having sexual dysfunction with those of normal volunteers as controls.

(Patients and Methods) Responses from 335 patients with sexual dysfunction and 490 normal volunteers aged from 20 to 39 years old were evaluated. We compared mean scores of each question for patients having sexual dysfunction with those for controls. Discriminant analysis was used for evaluating which questions contributed more strongly to discriminating patients having the disease from controls. The analysis was also used for validating the questionnaire.

(Results) Mean scores for patients with sexual dysfunction were significantly lower than those for controls in all questions. Nine of the 11 questions were statistically useful to discriminate these two groups with discriminant analysis. The analysis also revealed that questions about frequency of erection, rigidity of the erectile penis and duration of erection highly contributed to discriminate these two groups. The discriminant analysis achieved high sensitivity and specificity for classifying the groups.

(Conclusion) These results suggest that the use of the Sapporo Medical University-sexual function questionnaire is valid for discriminating patients with sexual dysfunction from subjects with normal sexual function.

Key words : sexual function questionnaire, discriminant analysis.

要旨：(背景と目的)性機能質問紙は，患者の自覚症状を具体化あるいは数量化可能な点で，性機能障害 の診断，治療効果の評価に有用である．今回我々は札幌医大式性機能質問紙を用いて性機能障害患者と 正常者の回答得点を比較検討し，この質問紙の妥当性について検討した.

(対象と方法) 性機能外来初診患者 335 例を性機能障害群，一般に性機能正常と思われる 20 代，30 代の成人病検診受診者 490 例を正常群とした. 2 群間において各々の質問項目における平均回答得点を

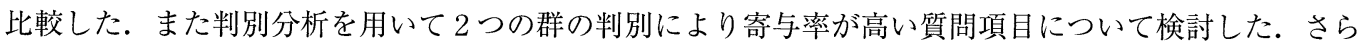
に求められた分類関数を用いて対象を分類し，予測された分類の判別的中率を求めた. また性機能障害 群において, 4 週以内に再度回答の得られた 24 例を対象に 2 回の回答得点の相関係数を求め, この質問 
紙の再現性について検討した.

(結果)すべての質問項目において，性機能障害群の平均回答得点は正常群に比べ有意に低かった，判 別分析では, 全 11 項目中 9 項目が 2 つの群の判別に有用な変数となり, 勃起頻度, 陰茎硬度, 勃起持続 時間の質問で判別の寄与率が高かった. 分類関数により対象を分類すると, 予測された分類の判別的中 率は $93.5 \%$ であった，再現性においては，2 回の回答得点の相関係数は平均 0.779 であった.

(結論)札幌医大式性機能質問紙は，性機能障害患者と正常者の判別が可能で，妥当性を有すると考え られた。

キーワード：性機能質問紙，判別分析

\section{緒言}

性機能障害を訴える患者の病態の把握にあたっては まず詳細な問診が重要である。しかし性機能に関する 自覚症状を問診により正確に把握することは患者の羞 恥心，見栄などの問題もあり比較的困難なことが少な くない.このような場合, 自己記入式のアンケート型 質問紙を用いることにより，患者の自覚症状をある程 度具体化, あるいは数量化することが可能となり, 治 療効果なども評価しやすい。このような背景から我々 は, 札幌医大式性機能質問紙を用いて性機能障害の診 断, 治療効果の評価などに役立ててきた。 その成果の 一つとして，加齢による性機能低下を明らかとしてき た . 今回我々は札幌医大式性機能質問紙の妥当性を 検討する目的で, 性機能障害を有する例と有さない例 との回答得点にどのような違いがあるかについて,さ らに両者の判別が可能か否かについて検討を行った.

\section{対象と方法}

1. 対象

札幌医大式性機能質問紙（以下，質問紙と略す）に 回答の得られた, 1992 年 1 月より 1997 年 12 月までの 性機能外来を初診した性機能障害患者 335 例を性機能 障害群とした。性機能障害群は, 器質性勃起障害, 機 能性勃起障害, 射精障害, 性欲障害, 腔内射精障害例 などが含まれている，性機能障害群の平均年齢は 51.2 歳であった。一方，一般に性機能正常と思われる 20 代，30 代の成人病検診受診者で，質問紙に回答の得ら れた 490 例を正常群とした. 平均年齢は 32.5 歳であっ た．今回の対象は，すべて妻またはパートナーを有す る男性とした。

\section{2. 質問項目}

質問紙は，まず妻やパートナーの有無や喫煙・飲酒 歴・既往歴などの質問，さらに生活環境におけるスト レスの有無などの質問に続いて，性機能に関する質問 の順で構成されている.

性機能に関する質問項目は，妻の協力度，性生活の
満足度, 性生活の潤い, 性交頻度, 視覚性欲, 接触性 欲, 早朝勃起, 勃起頻度, 陰茎硬度, 勃起持続時間, 射精頻度の 11 項目を取り上げた(表 1). 各質問項目に 対する回答は, 0 点から 5 点までの 6 段階で評価した.

3. 性機能障害群と正常群の平均回答得点の差の検 討

性機能障害群と正常群における各質問に対する平均 回答得点の差について検討した. なお今回の性機能障 害群の症例は, 器質性勃起障害と機能性勃起障害の症 例などが混在しているので, 器質性勃起障害の症例が 比較的少なく, 比較的障害の程度が低いと思われる 20 代, 30 代の性機能障害群と正常群の間に打いても同様 の検討を行った. 2 群間の平均回答得点の差は, MannWhitney U-test を用いて検定した.

4. 判別分析による性機能障害群と正常群の判別力 の検討

ステップワイズ判別分析を行うことによって，2つ の群を判別する際に有用な各変数が選択される21. 今 回の質問項目の中で, 性機能障害群と正常群の判別に 有用な各変数を求め, 選択された変数による判別関数 を求めた. 次に各变数と判別関数との相関を表す構造 係数を求め, 2 つの群の判別により寄与率が高い質問 項目を検討した。 また今回の対象群全体において各変 数の間の単相関を求め, 相関性のある質問項目につい て検討した。

判別分析により，各ケースがどの群に属しているか を予測する分類関数が求められる ${ }^{2)}$. 各ケースごとに 各質問項目の回答得点を性機能障害群, 正常群それぞ れの分類関数に代入すると, 合計スコアの大きい方の 群に分類される. そこで最後に実際に観測された分類 と, 今回分類関数によって子測された分類を比較し, その敏感度, 特異度, 全体の判別的中率を求めた。

また性機能障害群において，エレクトメーター使用 による夜間睡眠時勃起検查上，器質性勃起障害の患者 の含まれる割合が少ないと思われる院茎周最大増加值 
表 1 札幌医大式性機能質問紙より一部抜粋(性機能に関する質問項目)

1. 奥様(または扔相手の方)はセックスに 5 . 性的な絵や映画を見て興奮しますか？ 関して協力的ですか?(妻の協力度)
0 非協力的である
1 あまり協力的でない
2 やや協力的である
3 協力的である
4 かなり協力的である
5 極めて協力的である

2. 全体として現在の性生活に満足してい ますか?(性生活の満足度)
0 非常に不満である
1 かなり不満である
2 やや不満である
3 満足している
4 かなり満足している
5 極めて満足している

3.あなたの性生活は，生活に潤いを与え ていると思いますか? (性生活の潤い)
0 全く与えていない
1 あまり与えていない
2 やや与えている
3 与えている
4 かなり与えている
5 極めて与えている

4. 現在のあなたのセックスの回数は, 次 のどれですか? (性交頻度)
0 全くない
1 月に 1 回未満
2 月に $1 \sim 2$ 回
32 週に $1 \sim 2$ 回
4 週に $1 \sim 2$ 回
5 週 3 回以上

9. その時の陰茎の硬さはいかがですか？ (陰茎硬度)

$\begin{array}{ll}0 & \text { 全く興奮しない } \\ 1 & \text { あまり興奮しない } \\ 2 & \text { やや興奮する } \\ 3 & \text { 興奮する } \\ 4 & \text { かなり興奮する } \\ 5 & \text { 極めて興奮する }\end{array}$

0 全く硬くならない

1 わずかに硬くなる程度である

2 不充分で腔内挿入不能

3 やや不充分だが腔内挿人可能

4 かなりの硬さがある

5 完全に硬くなる

6. 女性に, 性的な雲囲気で体を触られると セックスしたくなりますか？(接触性欲)
0 全くならない
1 あまりならない
2 ややしたくなる
3 したくなる
4 かなりしたくなる
5 極めてしたくなる

10. 勃起の持続時間は充分ですか? (勃起 持続時間）
0 非常に不充分である
1 かなり不充分である
2 やや不充分である
3 充分である
4 かなり充分である
5 極めて充分である

7. 朝目覚めたとき, 勃起しているのに気 付くことがありますか? (早朝勃起)
0 全く気付かない
1 あまり気付かない
2 時々気付く
32 日に 1 回は気付く
4 しばしば気付く
5 いつも気付く

11. セックスまたは自慰を行った時，どの 程度の頻度で射精できますか?(射精 頻度）
0 全く射精できない
1 あまり射精できない
2 時々射精できる
32 回に 1 回は射精できる
4 しばしば射精できる
5 いつも射精できる

表 2 性機能障害群と正常群における各質問の平均回 答得点の差の検討

\begin{tabular}{lccc}
\hline \multirow{2}{*}{ 筫問項目 } & \multicolumn{2}{c}{ 平均回答得点 $(\mathrm{mean} \pm \mathrm{S.D})}$. & \multirow{2}{*}{$\mathrm{p}$ 值* } \\
\cline { 2 - 3 } & $\begin{array}{c}\text { 性機能障害群 } \\
(\mathrm{n}=335)\end{array}$ & $\begin{array}{c}\text { 正常群 } \\
(\mathrm{n}=490)\end{array}$ & \\
\hline 妻の協力度 & $2.4 \pm 1.4$ & $2.7 \pm 1.1$ & $\mathrm{p}=0.0003$ \\
性生活の満足度 & $1.0 \pm 1.0$ & $2.8 \pm 0.8$ & $\mathrm{p}<0.0001$ \\
性生活の潤い & $1.3 \pm 1.2$ & $2.6 \pm 1.0$ & $\mathrm{p}<0.0001$ \\
性交頻度 & $0.9 \pm 1.2$ & $2.8 \pm 1.2$ & $\mathrm{p}<0.0001$ \\
視覚性欲 & $1.7 \pm 1.0$ & $2.7 \pm 1.0$ & $\mathrm{p}<0.0001$ \\
接触性欲 & $2.1 \pm 1.2$ & $2.8 \pm 1.1$ & $\mathrm{p}<0.0001$ \\
早朝勃起 & $1.6 \pm 1.4$ & $2.9 \pm 1.5$ & $\mathrm{p}<0.0001$ \\
勃起頻度 & $1.7 \pm 1.5$ & $4.6 \pm 0.9$ & $\mathrm{p}<0.0001$ \\
陰茎硬度 & $1.9 \pm 1.3$ & $4.3 \pm 0.7$ & $\mathrm{p}<0.0001$ \\
勃起持続時間 & $0.8 \pm 1.0$ & $3.3 \pm 1.0$ & $\mathrm{p}<0.0001$ \\
射精頻度 & $2.3 \pm 2.0$ & $4.8 \pm 0.6$ & $\mathrm{p}<0.0001$ \\
\hline & & 3 & $*$ Mann-Whitney U test
\end{tabular}

表 320 代, 30 代の性機能障害群と正常群における 各質問の平均回答得点の差の検討

\begin{tabular}{|c|c|c|c|}
\hline \multirow[b]{2}{*}{ 質問項目 } & \multicolumn{2}{|c|}{ 平均回答得点 $($ mean \pm S.D.) } & \multirow[b]{2}{*}{$\mathrm{p}$ 值* } \\
\hline & $\begin{array}{c}\text { 性機能障害群 } \\
(\mathrm{n}=81)\end{array}$ & $\begin{array}{c}\text { 正常群 } \\
(\mathrm{n}=490)\end{array}$ & \\
\hline 妻の協力度 & $2.9 \pm 1.2$ & $2.7 \pm 1.1$ & $\mathrm{p}=0.1105$ \\
\hline 性生活の満足度 & $1.0 \pm 1.0$ & $2.8 \pm 0.8$ & $\mathrm{p}<0.0001$ \\
\hline 性生活の潤い & $1.2 \pm 1.1$ & $2.6 \pm 1.0$ & $\mathrm{p}<0.0001$ \\
\hline 性交頻度 & $1.1 \pm 1.4$ & $2.8 \pm 1.2$ & $\mathrm{p}<0.0001$ \\
\hline 視覚性欲 & $2.2 \pm 1.0$ & $2.7 \pm 1.0$ & $\mathrm{p}<0.0001$ \\
\hline 接触性欲 & $2.7 \pm 0.1$ & $2.8 \pm 1.1$ & $\mathrm{p}=0.3528$ \\
\hline 早朝勃起 & $2.4 \pm 1.6$ & $2.9 \pm 1.5$ & $\mathrm{p}<0.0001$ \\
\hline 勃起頻度 & $2.7 \pm 1.8$ & $4.6 \pm 0.9$ & $\mathrm{p}<0.0001$ \\
\hline 陰茎硬度 & $2.6 \pm 1.3$ & $4.3 \pm 0.7$ & $\mathrm{p}<0.0001$ \\
\hline 勃起持続時間 & $1.2 \pm 1.3$ & $3.3 \pm 1.0$ & $\mathrm{p}<0.0001$ \\
\hline 射精頻度 & $3.2 \pm 1.9$ & $4.8 \pm 0.6$ & $\mathrm{p}<0.0001$ \\
\hline
\end{tabular}


表 4 性機能障害群と正常群を判別する際に選択され た各変数と, 各々の構造係数

\begin{tabular}{ll}
\hline 妻の協力度 & 0.1189 \\
性生活の満足度 & 0.6085 \\
性交頻度 & 0.4757 \\
接触性欲 & 0.1813 \\
早朝勃起 & 0.2937 \\
勃起頻度 & 0.7432 \\
陰茎硬度 & 0.7321 \\
勃起持続時間 & 0.7286 \\
射精頻度 & 0.5569 \\
\hline
\end{tabular}

*選択されない変数 性生活の潤い 視鸴性欲

(以下 $\triangle \mathrm{NPT}) 30 \mathrm{~mm}$ 以上の症例 81 例 と, $\triangle \mathrm{NPT} 30$ $\mathrm{mm}$ 未渵の症例 252 例の間でも判別分析を施行し, 分 類関数により対象を分類して敏感度，特異度，判別的 中率を求めた。

\section{5. 再現性の検討}

性機能障害群のうち，4週間以内に再度同じ質問紙 に回答の得られた 24 例を対象に, 2 回の回答得点の相 関係数を求め,この質問紙の再現性について検討を 行った. 今回の 24 例については, 症状の強弱, 障害の 程度は様々で，特に症例を選定していない. 24 例の平 均年齢は $53.4 （ 19$ ～83）歳であった.

\section{結果}

1. 性機能障害群と正常群の平均回答得点の差の検 討

性機能障害群と正常群における各質問項目に対する
平均回答得点の差の検討においては，すべての質問項 目において，正常群に比べて性機能障害群の回答得点 は有意に低かった (表 2)。機能性勃起障害の症例が多 く含まれ，また比較的障害の程度が低いと思われる 20 代, 30 代の性機能障害群と正常群において同様の検討 を行ったところ，妻の協力度，接触性欲の 2 項目を除 いた 9 項目でやはり両群間の平均回答得点に有意差が 認められた（表 3 ）。

2. 判別分析による性機能障害群と正常群の判別力 の検討

ステップワイズ判別分析を行うと，2つの群を判別 する際に選択された変数は2 ${ }^{2)}$ 性生活の潤い, 視覚性欲 に関する質問 2 項目を除いた 9 項目であった（表 4）。 またどの変数がより判別関数への相関が高いかを表す 構造係数を求めると, 勃起頻度, 陰茎硬度, 勃起持続 時間の順でその值が高かった。

今回の対象群全体において各変数の間の単相関を求 めると, 勃起頻度, 陰茎硬度, 勃起持続時間のそれぞ れの項目間の相関係数は高かったが，その地の項目間 の相関性はあまり見られなかった（表 5).

次に，判別分析により求められた分類関数によって 予測された分類と，実際に観測された分類との比較を 行った. 正常群，性機能障害群のそれぞれの分類関数 を表 6 に示した，各ケース毎に各質問項目の回答得点 をそれぞれの分類関数に代入しケースを分類すると， 性機能障害群を正しく性機能障害群に分類する率，す なわち敏感度は 335 例中 292 例で $87.2 \%$ ，正常群を正 しく正常群に分類する率，すなわち特異度は 490 例中

表 5 各変数間の単相関係数

\begin{tabular}{l|c|c|c|c|c|c|c|c|c|c|c}
\hline & $\begin{array}{c}\text { 勃起 } \\
\text { 頻度 }\end{array}$ & $\begin{array}{l}\text { 陰茎 } \\
\text { 硬度 }\end{array}$ & $\begin{array}{c}\text { 持続 } \\
\text { 時間 }\end{array}$ & 満足度 & $\begin{array}{c}\text { 射精 } \\
\text { 頻度 }\end{array}$ & $\begin{array}{l}\text { 性交 } \\
\text { 頻度 }\end{array}$ & $\begin{array}{c}\text { 早朝 } \\
\text { 勃起 }\end{array}$ & $\begin{array}{l}\text { 接触 } \\
\text { 性欲 }\end{array}$ & $\begin{array}{c}\text { 妻の } \\
\text { 協力度 }\end{array}$ & 潤い & $\begin{array}{l}\text { 視覚 } \\
\text { 性欲 }\end{array}$ \\
\hline 陰茎硬度 & 1.000 & & & & & & & & & & \\
\hline 持続時間 & 0.873 & 1.000 & & & & & & & & & \\
\hline 満足度 & 0.764 & 0.776 & 1.000 & & & & & & & & \\
\hline 射精頻度 & 0.650 & 0.643 & 0.664 & 1.000 & & & & & & & \\
\hline 性交頻度 & 0.741 & 0.741 & 0.613 & 0.535 & 1.000 & & & & & & \\
\hline 早朝勃起 & 0.540 & 0.607 & 0.580 & 0.635 & 0.533 & 1.000 & & & & & \\
\hline 接触性欲 & 0.384 & 0.371 & 0.318 & 0.225 & 0.376 & 0.401 & 0.344 & 1.000 & & & \\
\hline 妻の協力度 & 0.250 & 0.203 & 0.229 & 0.394 & 0.185 & 0.318 & 0.142 & 0.175 & 1.000 & & \\
\hline 潤い & 0.509 & 0.492 & 0.523 & 0.612 & 0.395 & 0.591 & 0.336 & 0.279 & 0.386 & 1.000 & \\
\hline 視覚性欲 & 0.503 & 0.480 & 0.430 & 0.383 & 0.446 & 0.420 & 0.395 & 0.566 & 0.245 & 0.363 & 1.000 \\
\hline
\end{tabular}


表 6 正常群, 性機能障害群のそれぞれの分類関数

\begin{tabular}{|c|c|c|c|}
\hline 分類関数 & 正常群 & 性機能障害群 & \\
\hline 勃起頻度 & $\times 0.3681$ & $x-0.44989$ & \\
\hline 陰茎硬度 & $\times 2.1066$ & $\times 1.53212$ & 合計スコアが \\
\hline 持続時間 & $\times 0.9279$ & $\times-0.32519$ & $X>Y$; 正常群 \\
\hline 満足度 & $\times 1.9403$ & $\times 0.52723$ & $X<Y$; 性機能 \\
\hline 射精頻度 & $\times 1.1755$ & $\times 0.63744$ & 障害群 \\
\hline 性交頻度 & $x-0.0731$ & $x-0.47314$ & \\
\hline 早朝勃起 & $x-0.0225$ & $\times 0.17125$ & \\
\hline 接触性欲 & $\times 0.9754$ & $\times 1.18638$ & \\
\hline 妻の協力度 & $\times 0.7051$ & $\times 1.19166$ & \\
\hline 合計 & $\mathrm{X}$ & $\mathrm{Y}$ & \\
\hline
\end{tabular}

表 7 実際に観測された分類と今回の分類関数を用い て予測された分類との比較

\begin{tabular}{lcrrrrr}
\hline & \multirow{2}{*}{ 群 } & \multicolumn{3}{c}{ 予測された分類 } & \multirow{2}{*}{ 合計 } & 的中率(\%) \\
\cline { 3 - 6 } & & 性機能障害 & 正常 & & \\
\hline 観測され & 性機能障害 & 292 & 43 & 335 & 87.2 (敏感度) \\
た分類 & 正常 & 11 & 479 & 490 & 97.8 (特異度) \\
\hline & 合計 & 303 & 522 & 825 & 93.5 \\
\hline
\end{tabular}

479 例で $97.8 \%$ ，合計の判別的中率は $93.5 \%$ であった (表 7).

性機能障害群において, $\triangle \mathrm{NPT} 30 \mathrm{~mm}$ 以上の症例 81 例と, $\triangle \mathrm{NPT} 30 \mathrm{~mm}$ 未満の症例 252 例の間で判別分析 を施行し，求められた分類関数により対象を分類する と, 敏感度は $21.0 \%$ ，特異度は $95.6 \%$ であり，合計の 判別的中率は $77.5 \%$ であった。

\section{3. 再現性の検討}

性機能障害例 24 例においての検討では, 各質問項目 における 2 回の回答得点の相関係数はそれぞれ高く (表 8)，平均 0.779 であった.

\section{考 察}

高齢化社会を迎え QOL を重視する状況下で, 性機 能への関心が高まりつつある，性機能障害を訴えて外 来を受診する患者が増えつつある一方で, 最近では骨 盤内手術後の性機能障害 ${ }^{3}$, あるいは前立腺肥大症, 前 立腺癌などに対する抗アンドロゲン剂投与時の性機能 障害などについても関心が持たれている(4) 。) その 際, 性機能障害の程度または状況を把握する上で, 自 己記入式の質問紙は, 非常に簡便かつ有用であると思 われる ${ }^{7}$. 特に性機能に関する症状に関しては, 患者が 適切な語句を知らなかったりする場合もあり，実際の 性機能の状態を泌尿器科医が的確に評価できないこと
表 8 各質問項目における 2 回の回答得点の相関係数 (対象；性機能障害例 24 例)

\begin{tabular}{ll}
\hline 妻の協力度 & 0.788 \\
性生活の満足度 & 0.699 \\
性生活の潤い & 0.518 \\
性交頻度 & 0.790 \\
視覚性欲 & 0.769 \\
接触性欲 & 0.811 \\
早朝勃起 & 0.830 \\
勃起頻度 & 0.826 \\
陰茎硬度 & 0.949 \\
勃起持続時間 & 0.767 \\
射精頻度 & 0.819 \\
\hline
\end{tabular}

も少なくない、これらの点で質問紙はより真実に近い 患者の自覚症状の状況を表現しているものと思われ る.

これまでにいくつかの性機能質問紙が作成され，そ の有用性も報告されている ${ }^{788}$. 1995 年に O'Leary ら が発表したA Brief Male Sexual Function Inventry $(\mathrm{BSFI})^{7)}$ は性欲 (頻度, 強さ), 勃起能 (勃起頻度, 陰 茎硬度，困難度），射精（困難度，精液量の問題度）, 問題度 (性欲, 勃起, 射精), 性生活の満足度の 5 つの 大問，11 の質問項目から成り, 質問数は札幌医大式質 問紙と同じである. 勃起, 射精の困難度, 問題度といっ た質問項目が多いのが特徴である。また 1997 年に Rosenらが発表した International Index of Erectile Function $(\mathrm{IIEF})^{8)}$ は, 勃起頻度, 陰茎硬度, 膣内㨂入 頻度, 勃起維持頻度, 勃起維持困難度, 性交頻度, 性 交の満足度, 性交の潤い, 射精頻度, 絶頂感頻度, 性 欲頻度, 性欲程度, 性生活の満足度, パートナーへの 満足度, 勃起能の満足度といった 15 の質問項目より成 り, 勃起能, 射精能, 性欲, 性交の満足度, 全体の満 足度の 5 項目を主成分とする質問内容で構成されてい る.

いずれの質問紙も，特に後者における質問内容は札 幌医大式質問紙と類似している，相違点としては，い ずれも早朝勃起の項目を含んでいないこと，困難度と いった質問項目があることなどが挙げられる.

著者らは, 1992 年に札幌医大式性機能質問紙を作成 し，現在まで性機能の評価に用いてきたが，今回はこ の質問紙の妥当性を検討する目的で，性機能障害を訴 える患者と正常者の間で各質問に対する回答得点に有 意差があるか, さらには性機能障害患者と正常者の判 別がある程度可能かを検討した。 
今回の検討の結果，札帽医大式性機能質問紙では, 性機能外来を受診した患者は機能性，器質性など勃起 障害の原因を問わず，各質問に対する平均回答得点が 正常群に対して有意に低かった。この差は，単なる計 算上のみの差ではなく，実際の質問紙の回答にあては めると 1 2 段階異なることを示し, 臨床上も意味があ る差と考えられた。

さらに性機能障害群の対象を 20 代，30 代の比較的 若年齢で，機能性勃起障害の患者が比較的多く含まれ ると思われる群に限って同様の検討を行っても，やは りほとんどの質問項目において性機能障害群の平均回 答得点は有意に低かった。従って，実際に器質的障害 がない可能性がある患者でも，性機能障害を訴える患 者の場合，質問紙の回答は正常者と判別可能であるこ とが判明した。

ステップワイズ判別分析を施行すると，今回性機能 障害群と正常群の判別の際に有意となる变数は 11 項 目中 9 項目で，大部分の質問項目が性機能障害群と正 常群の判別に有用であることが示された．さらに構造 係数を求めて 2 群の判別により寄与率が高い質問項目 を検討すると, 勃起頻度, 陰茎硬度, 勃起持続時間の 変数の順にその值が高く，勃起能自体に直接関連する 質問項目がより判別に寄与する度合いが高い傾向にあ ることがわかった．また，これら 3 項目間の単相関係 数は高いことから，性機能の低下を訴える者では自覚 的には勃起頻度, 陰茎硬度, 勃起持続時間の 3 要素と も比較的並行して低下している可能性があることが示 唆された。他の質問項目間の相関性はあまりなく，さ

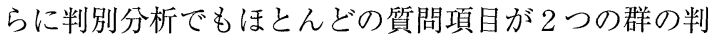
別に有用と選択されていることから，各々の質問項目 の独自の妥当性も示唆された.

分類関数によって対象を分類すると，予測された分 類の観測された分類に対する判別的中率は合計 $93.5 \%$ とかなり高率であった。以上より，この質問紙に扔け る性機能障害群と正常群の判別力は高いと考えられ た。

なお，性機能障害群の中で，器質性勃起障害の患者 の含まれる割合が少ないと思われる $\triangle \mathrm{NPT} 30 \mathrm{~mm}$ 以 上の症例と, $\triangle \mathrm{NPT} 30 \mathrm{~mm}$ 未満の症例で判別分析を施
行すると，その敏感度は $21.0 \%$ と低率であった。従っ て質問紙の回答得点のみで機能性, あるいは器質性勃 起障害を判別することは困難であると思われた.

本質問紙の回答得点における再現性の検討では，性 機能障害群においては各質問項目における 2 回の回答 得点の相関係数は高く，再現性を有すると思われた。

今回の札幌医大式性機能質問紙を用いた検討では, 性機能障害群と正常群の間では回答得点に有意な差が あり，この質問紙は性機能障害患者の症状を客観的に 把握する上で妥当性を有すると考えられた。

\section{文献}

1）佐藤嘉一, 堀田浩貴, 熊本悦明, 塚本泰司：加齢と 性機能. IMPOTENCE, 10, 273-280, 1995.

2）長田 理：多変量解析（3）-判別分析. 臨床医の ための統計テクノロジー, 初版, 81-88, 中外医学 社, 東京, 1996.

3) Fowler, F.J. Jr., Barry, M.J., Lu-Yao, G., Roman, A., Wasson, J. and Wennberg, J.E. : Patient reported complications and follow-up treatment after radical prostatectomy : the National Medicare experience : 1988-1990. Urology, 44, 46-51, 1994.

4）熊本悦朗，山口康宏，佐藤嘉一：Anti-androgen の性機能におよぼす影響. 泌尿紀要, 36, 213-216, 1990.

5) Gormley, G.J., Stoner, E., Bruskewitz, R.C., Imprrato-McGinley, J., Walsh, P.C., McConnell, J. D., Andriole, G.J., Geller, J., Bracken, B.R. and Tenover, J.S. : The effect of finasteride in men with benign prostatic hyperplasia. The Finasyeride Study Group. N.Engl. J.Med., 327, 11851191, 1992

6) Lynch, J.H. : Treatment of advanced prostate cancer. J.Fam. Pract, 37, 488-494, 1993.

7) O' Leary, M.P., Fowler, F.J., Lenderking, W.R., Sagnier, P.P., Guess, H.A. and Barry, M.J. : A brief male sexual function inventory for urology. Urology, 46, 697-706, 1995.

8) Rosen, R,C., Riley, A., Wagner, G., Osterloh, I.H., Kirkpatrick, J. and Mithra, A. : The International Index of Erectile Function [IIEF]; A multidimensional scale for assessment of erectile dysfunction. Urology, 49, 822-830, 1997.

(1999 年 5 月 11 日受付， 8 月 9 日受理) 